\title{
Security communities and the habitus of restraint: Germany and the U nited States on Iraq
}

\author{
CORNELIU BJOLA AND MARKUSKORNPROBST*
}

A bstract. Borrowing from $\mathrm{N}$ orbert Elias, we introduce the habitus of restraint to the study of security communities. This habitus constitutes a key dimension of the glue that holds security communities together. The perceived compatibility of practices emanating from the habitus that members hold fosters the collective identity upon which a security community is built. The violation of a member's habitus by the practices of another member, however, disrupts the reproduction of collective identity and triggers a crisis of the security community. Our analysis of Germany's reaction to W ashington's case for war against I raq provides empirical evidence for the salience of the habitus for the internal dynamics of security communities.

\section{Introduction}

A t first glance, it is surprising that Saddam $\mathrm{H}$ ussein triggered the deepest post-W orld War II rift in the usually amicable relationship between the U nited States and Germany. The two countries share many values that should have prevented action taken against a vicious dictator from becoming a contentious issue. Saddam H ussein's longstanding record of gross human rights abuses and aggression against other states should have been yet another reason to draw the two allies even closer together.

This scenario, however, failed to materialise. $\mathrm{N}$ ot only did the U nited States and Germany fail to find a common ground on Iraq. They even started to fundamentally question the nature of their relationship. Politicians exchanged several rounds of insults, ranging from $\mathrm{H}$ itler-Bush comparisons in Germany to likening Berlin's policy towards Iraq to the ones of Libya and North Korea in the U nited States. Intellectual elites and the public joined the chorus of sometimes severe criticism against the other country.

This study focuses on Germany's reaction. Why did G ermany react with such vigour to Washington's argument for war against Saddam Hussein? The existing literature cannot explain this empirical puzzle. The realist literature on alliances revolves around the concept of balancing. Germany, however, did not balance

\footnotetext{
* The authors would like to thank Emanuel A dler, Ted Hopf, Nancy K okaz, Homeira M oshir-Zadeh, Daniel N exon, Vincent Pouliot, $\mathrm{N}$ isha Shah, R uben Zaiotti and two anonymous reviewers for thought-provoking discussions and helpful suggestions on many aspects of the argument presented in this article.
} 
against the U nited States. Complex interdependence focuses on the sensitivity and vulnerability of a state vis-à-vis another. Washington's threats to punish its unreliable ally, however, did not make Berlin forgo its anti-war stance. Diversionary theories of war and peace cannot explain why some leading politicians followed the public sentiment and others did not. Finally, the constructivist literature on security communities fails to explain Germany's reaction because the internal dynamics of security communities remain little understood.

In order to improve our grasp of these dynamics, we introduce the "habitus of restraint' to the study of security communities. Our contention focuses on the ways of how enduring dispositions shape foreign policy. Following Norbert Elias's conceptualisation of the habitus, we identify two layers of deeply internalised predispositions that are distilled from history: a set of internal checks and selfrestraints against the use of force in world politics; and, underpinning these constraints, a durable set of anxieties and feelings of shame concerning past uses of force in international relations.

In a security community, some dimensions of a member state's habitus are idiosyncratic whereas others are shared with other members of the community. The extent to which a habitus is shared across a security community is unclear to its members. The habitus, being a second nature, does not lend itself to be put under scrutiny and reflected upon by those who hold it. Y et the perceived compatibility of practices generated through the habitus is apparent to the members. A member state may perceive a compatibility between the range of conceivable practices that emanate from its habitus on the one hand and its perception of the practices of other members on the other, or it may perceive a mismatch between the two.

We contend that the perception of compatibility or incompatibility has major repercussions for the internal dynamics of security communities. The perception of compatibility helps to reproduce collective identity. It assures the members that the community is firmly built on common ground. Standing on this common ground makes it possible for members to fine-tune their practices through bargaining and argumentation, and sometimes even to agree effortlessly on a set of practices that seem self-evident to everyone. The perception of incompatibility, by contrast, disrupts the collective identity on which the security community is built and propels it into crisis. Practices outside of a state's range of practices as delineated by its habitus violate this state's most taken-for-granted outlook on the world. This violation triggers demarcation from, instead of identification with, the member state whose practices are perceived to deny and reject the self-evident.

This process provides a plausible explanation for Germany's reaction against W ashington's case for war against I raq. Germany's habitus of restraint, constituted largely by constraints underwritten by anxiety and shame pertaining to the Second W orld War, clashed with Washington's practices. The latter were outside the range of conceivable practices that G ermany's habitus circumscribed. This made agreement on a course of action impossible, disrupted the identification with the U nited States, and gave rise to sharp demarcation.

This article is organised into six sections. First, we review the existing literature. Second, we discuss Elias's concept of the habitus and define it in a manner that makes it amenable to empirical research on security communities. Third, we describe the efforts by the U nited States to sway the world community into supporting its stance on I raq. F ourth, we investigate $G$ ermany's dominant habitus. F ifth, we analyse how 
Germany came to demarcate itself from the U nited States. Finally, the Conclusion summarises our findings and highlights the leads that the habitus of restraint provides for further research.

\section{Shortcomings of the existing literature}

F our literature-sets pertain to the research puzzle: realist scholarship on alliances, sensitivities and vulnerabilities of states as identified in the complex interdependence literature, the diversionary theory of war, and constructivist research on security communities. None of these approaches, however, can explain convincingly the schism between the $U$ nited States and $G$ ermany during the Iraq crisis.

According to the classical version of the realist approach,1 ${ }^{1}$ states protect their security by maintaining a favourable equilibrium of power in the system, either by increasing their military capabilities or by building military alliances. Stephen Walt's refinement of the balancing argument maintains that states do not balance against power alone, but against states that are perceived to pose the greatest threat. ${ }^{2} \mathrm{R}$ ealist scholarship, however, cannot explain the $G$ erman reaction to W ashington's stance on Iraq. G ermany did not try to balance against the $U$ nited States. G erman criticism of the Bush A dministration's stance on Iraq was not accompanied by any attempt to increase its military power or to engineer a military counter-alliance. Germany was also far from considering the $U$ nited States a threat to its security. The $U$ nited States possesses strong offensive capabilities and still maintains a significant number of troops in G ermany, but G ermany has not felt threatened by them. On the contrary, Germany continues to regard the US military presence on its soil as an essential component of its security and defence policies. ${ }^{3}$

The neo-liberal theory of complex interdependence contends that the flow of money, goods, information, and people across international borders has given rise to a relationship of asymmetrical interdependence among states. As a result, a high degree of sensitivity and vulnerability of a state's economy to global flows can be easily rendered by another state into a political leverage. ${ }^{4}$ Complex interdependence, however, does not provide a compelling account of G ermany's reaction. There are two reasons for this. First, the German economy was not particularly vulnerable and sensitive to a regime change in I raq. The level of trade between $\mathrm{G}$ ermany and I raq before the war was insignificant for the $\mathrm{G}$ erman economy. I raq ranked 138th with regard to imports and 83rd as far as exports were concerned among Germany's trading partners. Second, the G erman economy was very vulnerable and sensitive to U S reprisals for not going to war against Iraq. The U nited States represented the third most important exporting country ( 7.33 per cent or $€ 39,045.6 \mathrm{~m}$ ), and the

${ }^{1}$ H ans M orgenthau, Politics among Nations: the Struggle for Power and Peace (N ew Y ork: K nopf, 1973); K enneth N. Waltz, Theory of International Politics (R eading: A ddison-W esley, 1979); J oseph M. G rieco, 'A narchy and the L imits of Cooperation: A R ealist Critique of the $N$ ewest Liberal Institutions', International Organization, 42 (1988), pp. 485-507.

2 Stephen M. Walt, The Origins of Alliances (I thaca, N Y : Cornell U niversity Press, 1987).

3 J oschka F ischer, 'E urope and the F uture of the Trans-A tlantic R elations', 19 N ovember 2003, at: 〈http://www.auswaertiges-amt.de/www/en/laenderinfos〉.

4 R obert O. K eohane and J oseph S. N ye, Power and Interdependence (N ew Y ork: H arperCollins, 1989). 
second most important importing country (9.32 per cent or Euro 61,669.3 m) for Germany. ${ }^{5}$ If anything, complex interdependence would predict that Berlin should have been swayed by US pressure.

The diversionary theory of war is one of the most influential explanations of war. Staying in power is assumed to be the key preference of governing elites. War is a means that they readily use if it serves the purpose of staying in power. ${ }^{6}$ Of course, a diversionary theory of war cannot explain G erman criticism of the $U$ nited States. A fter all, it was Washington and not Berlin that went to war. But what about a diversionary theory of peace? $\mathrm{D}$ id the Chancellor, trailing in the opinion polls, reject the military option in order to exploit the anti-war sentiment of the electorate and secure his re-election?7

A t first glance, there seems to be evidence for this contention. G erhard Schröder rejected the military option at the beginning of his electoral campaign, which was seriously hampered by his failures in the economic realm. $\mathrm{H}$ is popularity among the electorate increased significantly after he had announced that G ermany would under no circumstances participate in a war against Iraq. The major problem of the diversionary explanation, however, is that only Schröder embarked on an anti-war course but not Edmund Stoiber, his challenger at the polls. F urthermore, leaders in other countries, such as J osé M aria A znar, Tony Blair, and Silvio Berlusconi, risked their political careers by going to war. Rational choice explanations, such as diversionary theories, assume nomothetic laws. Thus, it is puzzling for this approach if some leaders risk losing power because they act against the will of the populace, but others seize the opportunity and act in accordance with his or her interests in retaining power. ${ }^{8}$

The constructivist turn in International Relations theory was triggered by the shortcomings of rationalist approaches in explaining important international phenomena. Do ideational explanations fare better than the accounts discussed above? Considering the long-time friendship between the United States and G ermany, the literature on security communities seems apt to shed light on the G erman reaction. $\mathrm{K}$ arl $\mathrm{D}$ eutsch coined the security community concept. ${ }^{9} \mathrm{E}$ manuel $\mathrm{A}$ dler and $M$ ichael Barnett elaborated on the concept. A security community is much more than an alliance. It is a community of states defined by three characteristics: (1) shared identities, meanings, and values; (2) many-sided and direct relations; (3) a certain degree of long-term reciprocity. These conditions generate collective identification as well as mutual trust, and give rise to dependable expectations of peaceful change.

${ }^{5}$ F ederal Statistical Office, 'F oreign Trade', at: 〈http://www.destatis.de/themen/e/thm_aussen.htm〉.

6 Birger H eldt, 'D omestic Politics, A bsolute D eprivation, and the U se of A rmed F orce in Interstate Territorial Disputes: 1950-1990', Journal of Conflict Resolution, 43:4 (1999), pp. 451-78; A hmer Tarar, 'D iversionary Incentives and the Bargaining A pproach to W ar', International Studies Quarterly, 50:1 (2006), pp. 169-88.

7 Stefan K ornelius, for example, answers this question in the positive: Stefan K ornelius, 'D er G ourmet als K ellner: J oschka F ischers langer W eg', Internationale Politik, 58:9 (2003), pp. 31-7.

${ }^{8}$ A s far as Schröder is concerned, H elga H aftendorn makes a compelling argument that Schröder's electoral tactics influenced how he rejected the military option, i.e. very early and unilaterally, but not that he rejected it: Helga $\mathrm{H}$ aftendorn, 'Sicherheitspolitik im strategischen D reieck Berlin-Paris-W ashington', Politische Vierteljahresschrift, 45:1 (2004), p. 4. On a more general note, there are at least two important shortcomings of the diversionary theory. First, the preferences of elites are assumed instead of explained. Second, the critical question of where mass support for or mass opposition against war comes from in the first place is outside the scope of the theory.

${ }^{9} \mathrm{~K}$ arl D eutsch, Political Community and the North Atlantic Area (Princeton, N J: Princeton U niversity Press, 1957). 
Positive identification with one another prevents members of the security community from even considering the use of force against one another. ${ }^{10}$

The security community concept captures U S-G erman relations much better than the concepts of alliance or complex interdependence, which omit the ideational dimension of the relationship. U nfortunately, however, little has been written on the internal dynamics of security communities. ${ }^{11} \mathrm{H}$ ow is collective identity reproduced? How does the collective identity of a security community unravel? How does a security community overcome a collective identity crisis? A plausible explanation of this study's research puzzle requires answers to these questions.

Criticising Adler and Barnett for neglecting situations in which the collective identity is threatened, J anice $M$ attern introduces the concept of representational force to the study of security communities. According to the author, collective identity can be rescued from situations of crisis by the use of a 'narrative gun'. Government elites of one state pressure the elites of another state into forgoing their dissent by forcing them into the non-choice of either violating an aspect of their identity or complying with the collective identity as represented by the author of the representational force. 12

$M$ attern's argument is tailored to exactly the type of situation that occurred in the trans-A tlantic security community between $\mathrm{G}$ ermany and the $\mathrm{U}$ nited States prior to the $U$ nited States-led military operation in I raq. D oes her argument help to explain the sharp disagreement between $\mathrm{G}$ ermany and the $U$ nited States about the resort to force against Saddam Hussein? The two states failed to reach a consensus on a vital issue. A ccording to $M$ attern, the two states or at least one of them should have used representational force to coerce the other back into the 'we-feeling'. The U nited States did exactly that. George W. Bush made clear that not supporting the U nited States meant leaving the common ground with the $U$ nited States: ' $E$ ither you are with us or you are against us'. ${ }^{13} \mathrm{D}$ onald R umsfeld put $\mathrm{G}$ ermany in the dubious company of Libya and Cuba when he listed the countries opposed to war. ${ }^{14}$ The narrative gun, however, did not have the effect that $M$ attern predicts. It did not help to fasten the security community. If anything, it made the diplomatic skirmishes between Germany and the U nited States even worse.

\section{H abitus and security community}

D espite the use of a 'narrative gun', G ermany continued to oppose the war against Iraq. What exactly was Germany defending so strongly, even at the risk of

${ }^{10}$ Emanuel A dler and M ichael Barnett, 'A Framework for the Study of Security Communities', in Emanuel A dler and M ichael Barnett (eds.), Security Communities (Cambridge: Cambridge U niversity Press, 1998), pp. 29-66.

${ }^{11}$ The literature on the socialisation of Central and Eastern Europe by the core members of the trans-A tlantic security community is a notable exception in this regard: F rank Schimmelfenning, 'International Socialization in the $\mathrm{N}$ ew Europe: Rational Action in an Institutional Environment', European Journal of International Relations, 6:1 (2000), pp. 109-39; M ichael Williams and Iver N eumann, 'F rom A lliance to Security Community: N A TO, R ussia, and the Power of Identity', Millennium, 29:2 (2000), pp. 357-87.

12 Janice Bially M attern, 'The Power Politics of I dentity', European Journal of International Relations, 7:3 (2001), pp 349-97.

${ }^{13}$ G eorge W. Bush, quoted in Algemeen Dagblad, 14 F ebruary 2002.

14 D onald Rumsfeld, quoted in Tagesschau, 6 A pril 2003. 
undermining the relationship with its most important ally? This section borrows from $\mathrm{N}$ orbert Elias's conceptualisation of the habitus in order to address the internal dynamics of security communities.

Elias embeds his concept of the habitus into his theory of the civilising process. The author contends that, although the civilising process remains in its infancy, ${ }_{15}$ modern societies have made some - albeit anything but irreversible - progress towards deeply internalising an aversion against cruelty and violence. L earning was the key mechanism that gave rise to this aversion. G reater control of violence and aggression in the modern state was accompanied by a changing sensibility towards violence and cruelty to the extent that such acts became gradually morally repugnant and 'progressively thrust behind the scenes of people's communal life'. ${ }^{16}$

Elias provides four important clues about the constitution of this habitus. First, the habitus is made up of constraints about the use of force. ${ }^{17}$ Second, the constraints that make up the habitus are underpinned by deeply-seated anxieties and feelings of shame.18 Third, the restraints that make up the habitus are distilled history. A nation's historical practices and experiences become sedimented into its habitus. ${ }^{19}$ F ourth, the habitus is deeply internalised. Elias maintains that fears and shamealong with the constraints they buttress - are initially not internalised but their existence is dependent on overt sanctioning potential by, say, a chief or a monarch. $Y$ et over time, they sink in. ${ }^{20}$ Elias's habitus, ther efore, is in H egel's words, 'a second nature'21 or in Bourdieu's words, 'history turned into nature.'22 The habitus is distilled history that is deeply ingrained and taken for granted.

It is not that Elias's work is without its problems. Elias's Civilising Process was published at the eve of the Second W orld W ar and the H olocaust. R eacting to these catastrophes, much of his later work sought to comprehend this decivilising process rather than a civilising process. ${ }^{23}$ Elias never problematised the concept of civilising even though the label 'civil' may actually be a dangerous tool in the hands of a Self that is eager to brag about its supposed superiority and to discriminate against the Other based on its alleged inferiority. It is not quite clear whether Elias' underlying assumptions about human nature are warranted. $\mathrm{H}$ e assumes human beings to be dangerous animals as long as they are unconstrained by the forces of the civilising process. $Y$ et some of the constraints that the civilising process imposes - including those that are deeply internalised - may not be as benign as Elias makes them out to

15 N orbert Elias, Zeugen des Jahrhunderts. Im Gespräch mit Hans Christian Huf (Berlin: U Ilstein, 1999), p. 86.

16 N orbert Elias, The Civilizing Process: Sociogenetic and Psychogenetic Investigations (Oxford: Blackwell, 2000), p. 365.

17 In his Civilizing Process the constraints ingrained in the habitus go somewhat beyond the use of force. $Y$ et Elias consistently emphasised the issue of the use of force and downplayed constraints pertaining to other aspects of social life. See his reflections on his work in Elias, Zeugen des Jahrhunderts, p. 67.

18 Elias, Civilising Process.

19 Norbert Elias, The Germans: Power Struggles and the Development of Habitus in the Ninteenth and Twentieth Centuries. Oxford: Polity, 1996, p. 19.

20 Elias, Civilising Process; Elias, Germans.

21 G eorg W ilhelm F riedrich Hegel, Enzyklopädie der philosophischen Wissenschaften (H amburg: F elix M einer, 1969), p. 340.

22 Pierre Bourdieu, Outline of a Theory of Practice (Cambridge: Cambridge U niversity Press, 1977), p. 78.

23 Elias, Germans. 
be. ${ }^{24} \mathrm{~F}$ inally, there is not just one habitus, but there are many habitus, which govern different spheres of life. Elias makes a strong case for a habitus that restrains actors in using force. $Y$ et other habitus encourage actors to use force, ${ }^{25}$ and again others have very little to do with physical force. ${ }^{26}$

D espite these problems, however, Elias's conceptualisation of the habitus as a habitus of restraint is very useful for making sense of the dynamics of security communities. We define the concept as a two-layered set of deeply ingrained and historically distilled predispositions: the first layer consists of a set of internal checks and self-restraints against the use of force in international politics; the second layer, underpinning these constraints, encompasses a durable set of anxieties and feelings of shame emanating from past experiences with the use of force.

To some degree, every security community shares a habitus of restraint, henceforth simply referred to as habitus. The very existence of a security community is dependent on this restraint. In a security community, member states do not even contemplate the use of force against one another any more. Restraint becomes a second nature. F urthermore, the habitual restraint also provides much needed shared orientation for the security community in its interaction with the outside. Security communities do not use force on a random basis regardless of any predispositions about what distinguishes legitimate from illegitimate uses of force.

A security community, however, is not a monolithic bloc. It consists of member states. A s Elias points out correctly, these member states have different histories and distil these histories into different habitual restraints as well as into different sentiments of fear and shame that underpin these restraints. Of course, this does not mean that the habitus of a nation ends abruptly at its territorial borders. Some aspects of the habitus that are dominant in member states are shared across the community. $Y$ et others are peculiarities arising from how nations sediment their own histories into the habitus.

The extent to which a member state perceives a compatibility between the range of conceivable practices that emanate from its habitus and the practices of another member is of key importance for the dynamics of a security community. Compatibility fosters the reproduction of the collective identity that holds the security community together and provides the possibility to reach agreement on a course of action. In some cases, this harmonisation occurs effortlessly and virtually automatically. In other cases, it is the outcome of argumentation and bargaining processes. Incompatibility, by contrast, not only makes a common course of action impossible but it also disrupts the collective identity that holds the security community together. It shows a member that the taken-for-granted foundation for acting on an issue area of utmost importance - the use of force - turns out to be rejected by a fellow member. The disruption of the collective identification process gives rise to a crisis of the security community.

This rupture threatens the very existence of a security community if the mismatch pertains to the use of force by a member of a security community against another

${ }^{24}$ M ax Horkheimer and Theodor A dorno, Dialektik der Aufklärung: philosophische Fragmente (A msterdam: Querido, 1947), M ichel F oucault, Histoire de la sexualité, vol. 1: La volonté de savoir (Paris: Gallimard, 1976, pp. 99-173).

25 Loïs Wacquant, Body and Soul: Notebooks of an Apprentice Boxer (Oxford: Oxford U niversity Press, 2004).

26 Pierre Bourdieu, The Logic of Practice (Stanford, CA : Stanford U niversity Press, 1990). 
member, because the habitual restraint vis-à-vis other members is the core feature of a security community. $Y$ et severe crises also occur if the mismatch is pertinent to the use of force against a non-member. Even in this case, the mismatch shakes the shared ideational foundation on which the security community is built. The crisis may be only temporary. The international constellation, for example, may change and the question of the use of force may no longer be on the agenda. $Y$ et the crisis may come to threaten the very existence of the security community if the perceived mismatch endures.

Does this account focusing on the habitus provide a plausible explanation for Germany's vigorous opposition to Washington's case for war against Saddam H ussein? D id Germany react with such vigour because W ashington's practices were outside the range of conceivable practices that Germany's dominant habitus delineated? Our empirical analysis proceeds in three steps. First, we provide an overview of the construction of the Iraqi threat and the advocacy to counter this threat through military force by the B ush A dministration. O ur analysis starts with 11 September 2001 and ends with the beginning of the war against I raq.

Second, we investigate the $G$ erman habitus. U ncovering the habitus is not an easy task. The habitus is deeply ingrained, which makes it difficult to detect. We chose to focus on discourse on major international crises since the end of the Cold War, in order to identify the habitus. In the heated debates during a crisis, actors invoke what they take for granted. Relating what appears to them most self-evident to the pervasive uncertainty of a crisis situation helps actors to cope with the situation. We analysed three grand debates on the use of force in G ermany since the end of the Cold W ar and prior to the controversy about regime change in I raq: the Second G ulf W ar in 1991, K osovo in 1998, and A fghanistan in 2001. We examine the debates in the Bundestag - the decisive chamber of the two-chamber Parliament in matters of foreign policy - and in the two leading news magazines Focus and Spiegel. ${ }^{27}$

Third, we trace the German reaction to the U S advocacy for war against I raq. W e use five clusters of sources in order to capture this reaction in detail: (1) interviews with decision-makers;28 (2) Bundestag debates;29 (3) Focus and Spiegel; (4) the three influential policy-orientated journals Internationale Politik, WeltTrends, and Aus Politik und Zeitgeschichte; and (5) public opinion data.

\section{Bush's resolve: call to arms}

The proposal to attack I raq had been pushed up on the political agenda of the Bush Administration in the period immediately after 11 September 2001.30 It became

27 The following Bundestag debates dealt in depth with the resort to force: Verhandlungen des deutschen Bundestags: Plenarprotokoll 12/2, 14 J anuary 1991; 12/3, 17 January 1991; 13/242, 19 J une 1998; 13/248, 16 October 1998. We analysed all issues of Focus and Spiegel from A ugust 2002 to $\mathrm{M}$ arch 2003.

28 W e interviewed decision-makers in the Chancellery (Chancellor's office), F oreign M inistry, M inistry of D efence, as well as the standing committees on foreign affairs and defence in the Bundestag. F or the most part, we use these interviews as background of our analysis and make only those interviewees explicit who agreed to be mentioned.

29 The following debates focused on the resort to force against I raq: Verhandlungen des deutschen Bundestags: Plenarprotokoll 15/25, 13 F ebruary 2003; 15/30, $12 \mathrm{M}$ arch 2003; and 15/32, $15 \mathrm{M}$ arch 2003.

30 Washington Post, 17 A pril 2004. 
official policy approximately a year later when the A dministration announced that confronting I raq pre-emptively was an essential part of the global War A gainst Terrorism. ${ }^{31}$ A ccording to W ashington, regime change in I raq was necessary in order to root out the possibility of weapons of mass destruction being traded and used against the $U$ nited States and its allies by Saddam H ussein and the terrorist networks that he allegedly supported.

The linchpin of the U S argument to attack I raq revolved around the notion of the imminence of the threat posed by the Iraqi regime. In his speech at the U nited Nations on 12 September 2002, U S President George W. Bush described the Iraqi regime as 'a grave and gathering danger,' seeking to acquire weapons of mass destruction, and cooperating with terrorist networks such as Al-Qaeda. ${ }^{32}$ In Washington's view, there was unambiguous evidence that Iraq posed such an imminent threat. Bush argued that various intelligence assessments and the systematic obstructions of the UN weapons inspections by Saddam Hussein provided sufficient proof that I raq possessed weapons of mass destruction and posed a threat to international peace and security by sponsoring terrorist networks.

$\mathrm{H}$ aving made up its mind about the threat that Iraq posed, the Bush Administration tried to persuade the international community of the necessity to take military action. I nitially, Bush's attempts were partly successful. The U nited N ations Security Council passed Resolution 1441 in November 2002, which threatened 'serious consequences' against Iraq if it failed to comply with the strengthened weapons inspections regime. The UN weapons inspectors continued their work for another five months. Washington's attempts to persuade the world community of more determined action against I raq, however, were seriously hampered by the lack of compelling proof for the imminence of danger. The weapons inspectors did not find weapons of mass destruction and pleaded for more time to complete their task.

At times, the Bush Administration dismissed questions about evidence by reversing the burden of proof. In the post-9/11 environment, Donald Rumsfeld argued, the nature of the evidence required for launching a military attack has significantly changed. The burden of proof no longer falls on the attacking side but on the side suspected to possess and develop weapons of mass destruction. ${ }^{33} Y$ et the U nited States also attempted to persuade potential allies through evidence. In an effort to strengthen the case for war, U S Secretary of State Colin Powell laid out the U S file of evidence on the I raqi weapons of mass destruction programmes before the UN Security Council.34

W ith the efforts to persuade not yielding the desired success, W ashington resorted to a policy of rewards and punishments in order to engineer the 'Coalition of the Willing'. This policy ranged from promises of developmental aid to threats of unspecified consequences, the reallocation of U S military bases abroad, cancellation of foreign and military aid, reduction of financial investments, and denial of access to

31 W hite H ouse, 'The N ational Security of the U nited States of A merica', 22 September 2002, at: $\langle$ http://www.whitehouse.gov/nsc/nss.html〉; Washington Post, 12 J anuary 2003.

32 G eorge W. Bush, 'R emarks by the President at Signing of the Joint R esolution', Speech given on 16 October 2002, at: 〈http://usinfo.state.gov/topical/pol/arms/02101603.htm〉.

33 D onald R umsfeld, 'Statement before the H ouse A rmed Services Committee on Iraq', 18 September 2002, at: 〈http://www.house.gov/hasc/openingstatementsandpressreleases/107thcongress/02-0918rumsfeld.html $\rangle$.

${ }^{34}$ Colin L. Powell, 'R emarks to the U nited N ations Security Council', 5 F ebruary 2003, at: $\langle$ http://www.state.gov/secretary/rm/2003/17300.htm〉. 
I raqi oil and reconstruction projects. Traditional allies were not exempted from such a treatment. Pentagon officials discussed, for instance, a plan to punish Germany's 'treachery and ineptitude' over I raq, by harming its trade and economy. ${ }^{35} \mathrm{D}$ espite these measures, however, Washington failed to get the stamp of U N approval for military action against I raq. On $17 \mathrm{M}$ arch 2003, the U nited States withdrew its proposal for a Security Council resolution explicitly authorising the use of force. Rejecting the calls in the international community to strengthen the weapons inspections regime, W ashington started its military campaign against Iraq on 19 $M$ arch.

This highlighted two important shifts in U S foreign policy. F irst, W ashington had moved away from multilateralism towards unilateralism. The Bush Administration was not willing to compromise on what it perceived to be a vital issue of foreign policy. R ichard Perle, chairman of the D efence Policy Board, Vice-President Dick Cheney and D efence Secretary D onald R umsfeld, as well as other close advisors to G eorge W. Bush such as R ichard A rmitage, Paul W olfowitz and D ouglas F eith, had advocated a more determined unilateralism since the end of the Cold War. A 1992 Pentagon Paper on 'D efence Policy Guidance', taken up later by the 'Project for a $\mathrm{N}$ ew A merican Century', argued that the U nited States should use its unchallenged military power to unilaterally pursue its own interests, and to maintain its global hegemony. ${ }^{36}$ R eturned to power with the Bush A dministration in 2000, the members of this neoconservative group pushed forcefully for a change of direction in US foreign policy. 37

Second, US foreign policy had embraced pre-emptive war. A ccording to the Bush Doctrine, imminent danger has to be countered with military force before it is too late. This is the central lesson of 11 September. ${ }^{38}$ The doctrine represents a major departure from prior international practices. The right of self-defence has been traditionally defined rather narrowly in order not to undermine the sovereignty and non-interference principles in international law, and due to the difficulties of unambiguously demonstrating the imminence of a threat prior to launching a pre-emptive attack. The ominous mentioning of the threat posed by the 'axis of evil' by President Bush in his 2002 State of the U nion Address hinted at possible other targets of pre-emptive attacks. ${ }^{39}$

\section{G ermany's habitus: constraints, anxiety, shame, and history}

U ndoubtedly, there have been changes in German foreign policy since reunification but the intersubjective foundation on which these changes have occurred has proved to be rather enduring. In the 1990s, three international crises triggered major debates

35 Observer, 16 F ebruary 2003.

36 Thomas D onnelly, 'R ebuilding A merica's D efenses: Strategy, F orces and R esources for a $\mathrm{N}$ ew Century', at: 〈http://www.newamericancentury.org/R ebuildingA mericasD efenses.pdf $\rangle$.

37 M aureen R amsay and Lionel Cliffe, 'W ar on Iraq: an honourable deception?' Contemporary Politics, 9:4 (2003), pp. 1-11.

38 White House, 'The N ational Security of the U nited States of A merica'.

39 George W. Bush, 'Speech on Iraq made in Cincinnati, Ohio', 8 October 2002, at: 〈http://news.bbc.co.uk/1/hi/world/americas/2309049.stm〉. This hint is more detailed in D avid F rum and R ichard Perle, An End to Evil: How to Win the War on Terror (N ew Y ork: Random House, 2003). 
on the use of force in world politics in German society: Iraq (1991), K osovo (1998), and A fghanistan (2001). These debates show that there is a dominant two-layered habitus in Germany, constituted by a set of deeply-seated constraints on the use of force and their underpinning sentiments of anxieties and shame. These sentiments are distilled from history, in particular the Second World War.

Interpretations of German history are translated into four dimensions of the habitus. The first and perhaps most influential dimension pertains to the nature of war. War is seen as nothing glorious but as a horrible phenomenon that causes large-scale suffering. When G ermans think of war, they think of the images of W orld War II: destroyed cities, large numbers of civilian and military casualties, terrified civilians, broken soldiers, and ethnic cleansing. The participation in the $1991 \mathrm{Gulf}$ War may have been disputed, but not the nature of war: H ans-J ochen Vogel, who opposed the war, emphasised that '[t]he images of this time [World War II] are constantly before my eyes. We feel and suffer with the victims in the entire region [M iddle East], with the people who die there.' 40 Those who argued in favour of the military option concurred. Otto G raf L ambsdorff invoked the images of the past and asserts: 'We know what we talk about [. . .]. War is not the father of all things, it is the father of all horror.' 41 Similar views were prevalent during the debates on K osovo and A fghanistan.42

Given the images of two world wars, Germans are highly sceptical about the possibility of a just conduct of war. A ir strikes, in particular, trigger collective memories of the bombing nights that reduced German cities to rubble. Vera W ollenberger claims that with the beginning of air strikes on Baghdad in 1991, 'war showed its true face. It is a campaign against the Iraqi people [...] It is a crime against humanity.' 43 W ollenberger was part of the pacifistic wing of the G reens. Its principal opponent within the party was J oschka F ischer. D espite all their disagreements, they agreed on the nature of war. F ischer described it as follows when he made his case in favour of intervention in A fghanistan: ' W ar is disgusting. There is no such thing as a clinically clean war. It is in the nature of war that there are innocent victims.' 44

The second dimension of the habitus pertains to the degree of readiness to use military force and is also based on the lessons of two world wars. W ar is justifiable only as absolute last resort. Various members of the Bundestag put it similarly to Heidemarie Wieczorek-Zeul: 'We Germans know what two world wars meant in terms of humanitarian suffering and horrible sacrifices. In our people, therefore, there is a deep seated scepticism and caution against any kind of sabre-rattling and the

40 H ans-J ochen Vogel, Verhandlungen des Deutschen Bundestags: Plenarprotokoll 12/3, 17 January 1991, p. 48.

41 Otto Graf Lambsdorff, Verhandlungen des Deutschen Bundestags: Plenarprotokoll 12/3, 17 J anuary 1991, p. 51. See also: Helmut K ohl, Verhandlungen des Deutschen Bundestags: Plenarprotokoll 12/3, 17 J anuary 1991, p. 46.

42 See, for example, W olfgang G erhardt, Verhandlungen des deutschen Bundestags: Plenarprotokoll 13/248, 16 October 1998, p. 23144; R udolf Scharping, Verhandlungen des deutschen Bundestags: Plenarprotokoll 13/248, 16 October 1998, p. 23149; G erhard Schröder Verhandlungen des deutschen Bundestags: Plenarprotokoll 14/198, 8 N ovember 2001, p. 19285; F riedrich M erz, Verhandlungen des deutschen Bundestags: Plenarprotokoll 14/198, 8 N ovember 2001, p. 19289.

43 Vera Wollenberger, Verhandlungen des Deutschen Bundestags: Plenarprotokoll 12/3, 17 J anuary 1991, p. 54.

44 J oschka Fischer, Verhandlungen des Deutschen Bundestags: Plenarprotokoll 14/198, 8 October 2001, p. 19293. 
playing down of the danger of war. '45 O ut of 50 speakers in the debates on the Second Gulf War, Kosovo and A fghanistan, every single one of them emphasised that the use of force must only be a means of absolute last resort, many of them using the legal terminology 'ultima ratio'. 46

The principal reason to use force as a last resort is embedded in the collective memory of $\mathrm{H}$ itler's regime. Dictators who attack other states or slaughter their own people need to be confronted before it is too late. A principal argument before the Second G ulf War was that Saddam H ussein had, in stark violation of international law, annexed another state. This, Otto G raf Lambsdorff and, similarly many others with him argued, had to be opposed by the international community: ' $[$. . . ] if nothing helps, if the aggressor does not let lose of its prey, do we then accept the violation of law and do we Germans forget the experiences where acquiescence to dictatorship eventually leads or may lead?' 47 The key term acquiescence also featured prominently during the K osovo debate. The world, and given their history, G ermans in particular, must not turn a blind eye to large-scale humanitarian suffering caused by a despotic regime. ${ }^{48} \mathrm{G}$ erald $\mathrm{H}$ äfner and A ngelika $\mathrm{K}$ öster-Loßack, for example, compare the $\mathrm{G}$ erman experience to K osovo. They caution:

that organised murder, expulsion and kidnapping of an entire people must never ever be accepted again and that we have to oppose murderers, even by the use of military force as last resort [... .]. We have to continue to transform an era of violence and suppression, as it was characteristic for much of the 20th century (of which we G ermans are especially guilty), into an era in which not terror and violence but tolerance, peaceful conflict resolution, and the abidance by law regulate the relations within and among states. ${ }^{49}$

45 H eidemarie W ieczorek-Zeul, Verhandlungen des Deutschen Bundestags: Plenarprotokoll 12/2, $14 \mathrm{~J}$ anuary 1991, p. 41. F or similar lines of argumentation, see $\mathrm{H}$ elmut K ohl, Verhandlungen des Deutschen Bundestags: Plenarprotokoll 12/3, 17 J anuary 1991, p. 46; H ans-J ochen Vogel, Verhandlungen des Deutschen Bundestags: Plenarprotokoll 12/3, 17 January 1991, p. 48; Otto G raf L ambsdorff, Verhandlungen des Deutschen Bundestags: Plenarprotokoll 12/3, 17 J anuary 1991, p. 46; Vera Wollenberger, Verhandlungen des Deutschen Bundestags: Plenarprotokoll 12/3, 17 J anuary 1991, p. 54; H elmut K ohl, Verhandlungen des Deutschen Bundestags: Plenarprotokoll 12/3, 17 J anuary 1991, p. 67; J oschka Fischer, Verhandlungen des Deutschen Bundestags: Plenarprotokoll 14/198, 8 October 2001, p. 19293.

46 Verhandlungen des Deutschen Bundestags: Plenarprotokoll 12/2, 14 J anuary 1991, pp. 21-55; Verhandlungen des Deutschen Bundestags: Plenarprotokoll 12/248, 16 O ctober 1998, pp. 23127-23161; 19283-18698. The shared benchmark does not guarantee shared conclusions about the application of the benchmark. During the 1991 debates on I raq, government and opposition disagreed whether the use of force was legitimate. The opposition argued that non-military means had not been exhausted yet, whereas the government endorsed the view of the Security Council that the use of force was a matter of last resort.

47 Otto Graf Lambsdorff, Verhandlungen des Deutschen Bundestags: Plenarprotokoll 12/2, 14 J anuary 1991, p. 32. See also Helmut K ohl, Verhandlungen des Deutschen Bundestags: Plenarprotokoll 12/2, 14 J anuary 1991, p. 22.

48 Of course, the habitus is, albeit quite enduring, not carved into stone. It evolves over time. There are some indications that episodes of the breakdown of Y ugoslavia, in particular Srebrenica, have become sedimented into the habitus. A feeling of shame for having stood by mass killings half a century after the $\mathrm{H}$ olocaust seems to have come to modify the constraints constituting the habitus (interviews with U Irike M erten, W infried N achtwei, and G ert W eisskirchen in Berlin, 24-25 January 2006). Y et only a study exploring the long durée of the habitus in detail can provide plausible insights into the way it changes.

49 G erald H äfner und A ngelika K öster-Loßack, Verhandlungen des Deutschen Bundestags: Plenarprotokoll 13/248, 16 October 1998, p. 23168. F or a similar view, see K laus K inkel, Verhandlungen des Deutschen Bundestags: Plenarprotokoll 13/248, 16 O ctober 1998, p. 23131; Gerhard Schröder, Verhandlungen des Deutschen Bundestags: Plenarprotokoll 13/248, 16 October 1998, p. 23136. 
The third dimension of the habitus concerns alliances. M etaphorically speaking, Germans are children of Konrad A denauer and not Wilhelm II. M ost Germans interpret the experiences of World Wars I and II as evidence that Germany must never ever embark on a Sonderweg (special path) again. This term, used by historians to describe the alliance policies (or lack thereof) by Wilhelm II, has become a pejorative term. Germany has to act in concert with its allies, but never unilaterally. Ulrich Irmer put this very clearly: 'No, we must not opt for Sonderwege when it comes to fulfilling our international duties. We must not even opt for Sonderwege if this demands taking difficult and most difficult decisions [resort to military force].'50 Instead of embarking on a Sonderweg, K inkel emphasised, G ermany needs to fulfil its 'European peace responsibility' and prove its 'reliability in the alliance'. 51 Wolfgang Bötsch cautioned that 'Germany must not stand apart' when its allies attempt to deal with crises. ${ }^{52}$ Schröder and F ischer stressed the need to act in concert with N ATO.53

Finally, the fourth dimension of the habitus pertains to the vision of a horizontal world order. The historical reference points are $\mathrm{G}$ ermany's role during the age of imperialism and Hitler's attempt at world domination. M uch in the same way as the Sonderweg has become a pejorative term, Realpolitik and Machtpolitik (power politics) have become reminders of a past from which most $\mathrm{G}$ ermans seek to distance themselves. In order to prevent the tragedies of the past from recurring, the current world order would have to be built on three principles: the rule of law, pluralism and dialogue, as well as partnership in crisis management. Gernot Erler's assertion in favour of the rule of law in international relations was a commonplace in all analysed debates: 'It remains our most fundamental persuasion that we have to be fully committed to a world order in which the power of the law triumphs over the power of the stronger'. ${ }^{54}$ The $\mathrm{U}$ nited $\mathrm{N}$ ations is seen as the principal guarantor of the rule of law in international relations. ${ }^{55} \mathrm{D}$ ialogue and co-operation have been key words in all three Bundestag debates. The principal means of resolving conflicts and preventing disputes from arising is the respect for the 'plurality of cultures', 56

50 U Irich Irmer, Verhandlungen des Deutschen Bundestags: Plenarprotokoll 13/248, 16 October 1998, p. 23151.

${ }^{51}$ K laus K inkel, Verhandlungen des Deutschen Bundestags: Plenarprotokoll 13/248, 16 October 1998, p. 23129.

52 W olfgang Bötsch, Verhandlungen des Deutschen Bundestags: Plenarprotokoll 12/2, 14 J anuary 1991, p. 30 .

53 G erhard Schröder, Verhandlungen des Deutschen Bundestags: Plenarprotokoll 14/198, 8 N ovember 2001, p. 19284.

54 G ernot Erler, Verhandlungen des Deutschen Bundestags: Plenarprotokoll 13/248, 16 October 1998, p. 23156.

55 H elmut K ohl, Verhandlungen des Deutschen Bundestags: Plenarprotokoll 12/3, 17 J anuary 1991, p. 47; A Ifred D regger, Verhandlungen des Deutschen Bundestags: Plenarprotokoll 12/3, 17 J anuary 1991, p. 49; K laus K inkel, Verhandlungen des Deutschen Bundestags: Plenarprotokoll 13/248, 16 October 1998, p. 23128; Wolfgang Gerhardt, Verhandlungen des Deutschen Bundestags: Plenarprotokoll 13/248, 16 October 1998, p. 23143; M ichael M üller, Verhandlungen des Deutschen Bundestags: Plenarprotokoll 13/248, 16 October 1998, p. 23166; Eberhard Brecht, Verhandlungen des Deutschen Bundestags: Plenarprotokoll 13/248, 16 October 1998, p. 23168; G erhard Schröder, Verhandlungen des Deutschen Bundestags: Plenarprotokoll 14/198, 8 November 2001, p. 19286; Peter Struck, Verhandlungen des Deutschen Bundestags: Plenarprotokoll 14/192, 11 October 2001, p. 18689.

56 J oschka Fischer, Verhandlungen des Deutschen Bundestags: Plenarprotokoll 14/192, 11 October 2001, p. 18693. 
'cultural dialogue', 57 'intercultural dialogue', 58 as well as co-operation and integration across cultures and states. ${ }^{59}$ If crises emerge despite these attempts to build bridges, they need to be managed by the international community and not by a hegemon. The $\mathrm{U}$ nited $\mathrm{N}$ ations on the world stage, and the European $\mathrm{U}$ nion as well as the Organization for Security and Co-operation in Europe are seen as the key actors of crisis management. 60

In short, the dominant habitus predisposes G ermany to be reluctant to support military interventionalism. $\mathrm{G}$ iven the predominant interpretation of $\mathrm{G}$ erman history, military force is seen as justifiable only in extraordinary circumstances, that is, if it is directed against a $\mathrm{Hitleresque}$ regime and if it is - in sharp demarcation from G ermany's past - part of a genuine multilateral effort.

\section{I raq delineated by the habitus: G ermany's criticism of the U nited States}

The habitus marked out a space of conceivable positions on the I raq crisis. A n unequivocal pro-war stance was outside this space. While the habitus made a range of positions on the Iraq issue possible, it predisposed Germany to a determined anti-war stance. The U nited States was accused of fighting a war for no legitimate reason and attempting to command, as opposed to consult, the world community. In the perception of many, Washington threatened to throw the world back into an era of domination. This perception triggered harsh criticism, sometimes even explicitly linking U S practices to G ermany's past attempts at world domination.

The discourse was dominated by two views: the majority was unambiguously opposed to the use of force; a minority refused to rule force out unilaterally. The minority view was articulated by the leadership of three of the four opposition parties in the Bundestag, Christian D emocratic U nion, the Christian Social U nion and the $F$ ree $D$ emocrats but not al ways backed on the grassroots levels. The news magazine Focus shared the ambiguous stance on the use of force.

Even the ambiguous minority used the habitus as the benchmark for its argumentation. T wo arguments were put forward against ruling force out. F irst, war as a last resort would be justified against Saddam $\mathrm{H}$ ussein. $\mathrm{H}$ e is a dictator who must

57 Rudolf Scharping, Verhandlungen des Deutschen Bundestags: Plenarprotokoll 13/248, 16 October 1998, p. 23149.

58 J oschka Fischer, Verhandlungen des Deutschen Bundestags: Plenarprotokoll 14/192, 11.10.01, p. 18693.

59 H elmut K ohl, Verhandlungen des Deutschen Bundestags: Plenarprotokoll 12/2, 14 J anuary 1991, p. 23; W illy Brandt, Verhandlungen des Deutschen Bundestags: Plenarprotokoll 12/2, 14 January 1991, p. 28; J oschka F ischer, Verhandlungen des Deutschen Bundestags: Plenarprotokoll 13/248, p. 16, October 1998, p. 23142; Wolfgang Schäuble, Verhandlungen des Deutschen Bundestags: Plenarprotokoll 13/248, 16 October 1998, p. 23140.

60 See, in particular: K laus K inkel, Verhandlungen des Deutschen Bundestags: Plenarprotokoll 13/248, 16 October 1998, p. 23128; W olfgang G erhardt, Verhandlungen des Deutschen Bundestags: Plenarprotokoll 13/248, 16 October 1998, pp. 23143-4; L udger Vollmer, Verhandlungen des Deutschen Bundestags: Plenarprotokoll, p. 23152; M ichael M üller, Verhandlungen des Deutschen Bundestags: Plenarprotokoll 13/248, 16 October 2001, p. 23166; Eberhard Brecht, Verhandlungen des Deutschen Bundestags: Plenarprotokoll 13/248, 16 October 2001, p. 23168; G erhard Schröder, Verhandlungen des Deutschen Bundestags: Plenarprotokoll 14/198, 8 N ovember 2001, pp. 19284-5; Peter Struck, Verhandlungen des Deutschen Bundestags: Plenarprotokoll 14/198, 8 N ovember 2001, p. 18689; J oschka F ischer, Verhandlungen des Deutschen Bundestags: Plenarprotokoll 14/198, 8 N ovember 2001, p. 18695. 
to be confronted before it is too late. M ichael Glos, for example, made the analogy with $\mathrm{H}$ itler explicit:

Nobody - and most definitely nobody within the trans-A tlantic community - wants war. We know the lessons of the history of two world wars [. . . ]. Y et we must keep in mind the consequences of pacifism in the last century. If the community of free nations had confronted $\mathrm{H}$ itler early enough through political and - as ultima ratio - military means, Germany and the world would have been spared of a lot.

A pplied to the case of Saddam H ussein, this lesson meant to pressure the dictator into complying with the weapons inspection regime through the threat of force. If this turned out to be insufficient, the international community would have to use force. ${ }^{61}$

Second, the decision to go to war would have to be a multilateral one. If Saddam H ussein failed to comply with the weapons inspectors regime, it would be up to the international community, including Germany, to decide together whether military force should be used or not. $\mathrm{N}$ o state should take a unilateral decision for or against war. The proponents of this multilateral decision accused Schröder of embarking on a new Sonderweg. H ans-D ietrich G enscher, the former foreign minister, criticised the 'hyper-G ermanness' of Schröder. M ichael G los and Wolfgang Schäuble compared Schröder to Wilhelm II.62 Edmund Stoiber warned that Schröder had left the path towards the Europeanisation of national foreign policies and had embarked on 'a renaissance of national Sonderwege. ${ }^{63}$ The Focus warned that Schröder was about to isolate $\mathrm{G}$ ermany and to foster a new $\mathrm{G}$ erman nationalism. ${ }^{64}$ Intellectuals were also part of the anti-Sonderweg chorus against Schröder. A rnulf Baring warned that Germany stood at the crossroads as it did in 1871. A G erman Way would lead to a disaster again. Only the embeddedness of Germany into the trans-A tlantic community would offer a promising future. ${ }^{65} \mathrm{~W}$ ilfried von Bredow warned that $\mathrm{N}$ ational Socialism had shown clearly that a $\mathrm{G}$ erman way could only lead into a catastrophe. ${ }^{66}$

This twofold argumentation for at least considering the use of force-from the beginning merely a minority view - weakened over time. The closer the war came and the more obvious Washington's unilateralism became, the weaker the advocacy became. ${ }^{67}$ The majority, however, unequivocally rejected the use of force from the outset. The benchmark for its argumentation was the same habitus that underpinned

61 Eckart von K laeden, Verhandlungen des Deutschen Bundestags: Plenarprotokoll 15/25, 12 F ebruary 2003, p. 1846; Christian Schmidt, Verhandlungen des Deutschen Bundestags: Plenarprotokoll 15/25, 12 F ebruary 2003, p. 1855; O. Berbalk et al., 'K ein Ja für nichts', Focus, no. 6, 3 F ebruary 2003, pp. 20-6.

62 M ichael G Ios, Verhandlungen des Deutschen Bundestags: Plenarprotokoll 15/25, 13 F ebruary 2003, pp. 1891-2; Wolfgang Schäuble, Verhandlungen des Deutschen Bundestags: Plenarprotokoll 15/25, 13 F ebruary 2003, p. 1901.

63 Edmund Stoiber, Verhandlungen des Deutschen Bundestags: Plenarprotokoll 15/32, 14 M arch 2003, p. 2521.

64 G. Bauer et al., 'Schröders A usweg', Focus, no. 33, 12 A ugust 2002, pp. 18-21; B. Bäumlisberger, 'K anzler: Ende der Show', Focus, no. 9, 24 F ebruary 2003, pp. 19-30; N icola Brüning et al., 'G lasklares Verwirrspiel', Focus, no. 49, 2 D ecember 2002, pp. 22-6; M ichael M utz et al. 'U neingeschränktes N ein', Focus, no. 37, 9 September 2002, pp. 28-9.

65 A rnulf Baring, 'Einsame M ittelmacht. Ohne die U SA gibt es keine Zukunft für D eutschland', Internationale Politik, 58:12 (2003), pp. 51-6.

66 Wilfried von Bredow, 'N eue Erfahrungen, neue M aßstäbe: G estalt und G estaltungskraft deutscher A ußenpolitik', Internationale Politik, 58:9 (2003), pp. 1-11.

67 In the Focus, for example, contributions critical of W ashington increased markedly: O. Berbalk et al., 'A merika im K rieg', Focus, no. 7, 10 F ebruary 2003, pp. 169-71; M. Bommersheim et al., 'Ist der K rieg noch zu stoppen?' Focus, no. 9, 24 F ebruary 2003, pp. 173-8; Peter Gruber, 'Schöne neue W elt', Focus, no. 12, 17 M arch 2003, pp. 218-22. 
the ambiguous proponents' reasoning. $Y$ et the opponents linked the habitus to the I raq crisis in a fundamentally different manner. They employed the last resort and alliance dimensions of the habitus for their argumentation against the use of force. A dditionally, they drew upon the nature of war and the world order dimensions to make their case against war.

The opponents of the military option rejected the argument that war was a last resort. A ccording to the Spiegel, the U S intervention was a 'war of aggression', 68 a 'crime', 69 'a war about the milk cow',70 and a 'crusade'. ${ }^{71}$ The U nited States was accused of insisting on war independently of the outcome of the weapons inspections. ${ }^{72}$ In Parliament, Social D emocrats and G reens criticised that war was anything but an ultima ratio in the case of I raq. F ischer emphasised that 'all peaceful means really have to be exhausted', but that this was 'not the case at all.'73 Schröder stressed that this did not mean appeasement. He proposed several measures to make the weapons inspections more effective. ${ }^{74} \mathrm{~A}$ number of politicians and political commentators compared N orth K orea and I raq. They questioned why the U nited States offered the former a dialogue whereas the latter awaited military action, although $\mathrm{N}$ orth Korea was more advanced with the development of weapons of mass destruction than Iraq. ${ }^{75}$ Public opinion data suggest that the public overwhelmingly supported his view that war against I raq would not have been a matter of last resort. E mnid surveys show that 61 per cent of the populace saw no legitimate reason for war in M ay 2002. This figure grew to 74 per cent in A ugust 2002, and to 83 per cent in F ebruary 2003. ${ }^{76}$

The opponents of force also rejected the argument that Germany had embarked on a dangerous Sonderweg á la W ilhelm II. Gert W eisskirchen argued vehemently against the comparison between Schröder and W ilhelm II. The former's goal is peace whereas the latter's was the aggrandisement of the German Empire by virtually any means. F urthermore, W eisskirchen contended, G ermany was not isolated at all. A majority of European U nion members was reluctant to participate in war. M any other nations, such as C hina and R ussia, also shared the $\mathrm{G}$ erman scepticism to attack I raq. ${ }^{77} \mathrm{~F}$ ischer accused the Christian D emocrats of trying to isolate $\mathrm{F}$ rance. ${ }^{78} \mathrm{M}$ any intellectuals joined the chorus that defended Schröder against the allegation of

68 D ieter Bednarz et al., 'D er Schachzug Saddams', Spiegel, no. 32, 5 A ugust 2002, p. 101.

69 Rudolf A ugstein, 'D ie Präventiv-K riegstreiber', Spiegel, no. 35, 26 A ugust 2002, p. 110.

70 Dieter Bednarz and J an Fleischhauer, 'K ampf um die M ilchkuh', Spiegel, no. 33, 12 A ugust 2002, p. 106; milk stands for oil.

$71 \mathrm{H}$ ans H oyng and G erhard Spörl, 'K rieg aus N ächstenliebe', Spiegel, no. 8, 17 F ebruary 2003, p. 90.

72 This view was expressed in Spiegel and Focus. See, for example, D ieter Bednarz et al., 'D er Schachzug Saddams' and Ottmar Berbalk et al., 'W asserdichte Beweise', Focus, no. 50, 9 D ecember 2002, pp. 49-53.

73 J oschka F ischer, Verhandlungen des Deutschen Bundestags: Plenarprotokoll 15/25, 13 F ebruary 2003, p. 1885.

74 G erhard Schröder, Verhandlungen des Deutschen Bundestags: Plenarprotokoll 15/25, 13 F ebruary 2003, p. 1878.

75 A number of deputies stressed this issue in the Bundestag: Gerhard Schröder, Verhandlungen des Deutschen Bundestags: Plenarprotokoll 15/25, 13 F ebruary 2003, p. 1875. G ernot E rler, Verhandlungen des Deutschen Bundestags: Plenarprotokoll 15/25, 13 F ebruary 2003, p. 1890. F or a more detailed argument, see also J oachim K rause, 'N ordkorea und I rak: U nterschiedliche M aßstäbe in der Bewertung', Internationale Politik, 58:2 (2003), pp. 43-8.

76 Emnid, Umfrage und Analyse, 3:4 (2003), p. 13. The following question was asked: 'D o you consider a military intervention by the U nited States in I raq justified?'

77 G ert W eisskirchen, Verhandlungen des Deutschen Bundestags: Plenarprotokoll 15/25, 13 F ebruary 2003, p. 1905. 
breaking off Germany's ties with its allies.79 Public opinion concurred again with Schröder. The public did not regard Germany as isolated. A ccording to an Emnid survey in September 2002, 56 per cent did not consider Germany isolated. In F ebruary 2003, this figure even increased to 73 per cent. 80

$Y$ et the opponents of military force did not only connect two of the habitus dimensions differently to the Iraqi crisis. They also emphasised two aspects of the habitus that the proponents of intervention did not address: the nature of war and world order. F ormer Chancellor Helmut Schmidt argued that G ermans understand the horrors of war much better than U S A mericans:

One thing is for sure: A pproximately half a century after the Second W orld War, A usschwitz, D resden and Stalingrad, the fear of war is even a bit greater in Germany than in other European states. The A merican nation, by contrast, has never experienced war in its own country. ${ }^{81}$

In the Bundestag, Christoph Zöpel made the same argument, but stressed that Europeans shared the fear of war. ${ }^{82}$ J oschka Fischer, L udger Vollmer and Gert Weisskirchen warned in vivid words of the consequences that a war against Iraq would have for Iraqi civilians.83 When the air strikes against Baghdad began, $\mathrm{H}$ ans $\mathrm{H}$ yong et al. immediately invoked the bombardment of D resden in the Spiegel:

W ith devastating aerial bombardments W ashington attempted to force Saddam H ussein into an early capitulation. [. . . . F or many observers, D resden came to mind when the pictures of the enormous fire power and pitiless destruction were sent around the globe. ${ }^{84}$

A $n$ equally forcefully articulated reason against intervention was based on the world-order dimension of the habitus. $M$ any anti-war advocates accused the $U$ nited States of violating the most basic lesson of international relations history: imperialism leads to instability and war. Only multilaterialism and dialogue can provide a peaceful international order. In the Bundestag, Schröder warned in diplomatic words that the might of the strong must not replace the might of the law in international relations. ${ }^{85}$ The resort to war in particular, Gernot Erler and Peter Struck emphasised, must not be the unilateral decision of the only remaining superpower but a

78 J oschka F ischer, Verhandlungen des Deutschen Bundestags: Plenarprotokoll 15/25, 13 F ebruary 2003, p. 1887.

79 See, for example: U Irich M enzel, 'Comeback der drei Welten: Der amerikanische Sonderweg und die A Iternativmacht Europa', Blätter für deutsche und internationale Politik, 48:12 (2003), pp. 1453-62; R ichard H erzinger, 'Siamesische Zwillinge: A merika und Europa streiten sich heftig - und gehören doch zusammen', Internationale Politik, 58:6 (2003), pp. 1-8.

80 Emnid, Umfrage und Analyse, 3:4 (2003), p. 15. The following question was asked: 'D o you consider the allegation justified that the federal government isolates the F ederal R epublic of Germany in the international community?'

81 Helmut Schmidt, 'D as ist grober U nfug', Spiegel, no. 6, 3 F ebruary 2003, pp. 36-41.

82 Christoph Zöpel, Verhandlungen des Deutschen Bundestags: Plenarprotokoll 15/25, 13 F ebruary 2003, p. 1907.

83 J oschka Fischer, Verhandlungen des Deutschen Bundestags: Plenarprotokoll 15/25, 13 F ebruary 2003, p. 1886; L udger Vollmer, Verhandlungen des Deutschen Bundestags: Plenarprotokoll 15/25, 13 F ebruary 2003, p. 1900, Gert W eisskirchen, Verhandlungen des Deutschen Bundestags: Plenarprotokoll 15/25, 13 F ebruary 2003, p. 1906.

$84 \mathrm{H}$ ans H oyng et al. 'H öllenfeuer in Baghdad', Spiegel, no. 13, 24 M arch 2003, pp. 16-17.

85 G erhard Schröder, Verhandlungen des Deutschen Bundestags: Plenarprotokoll 15/25, 13 F ebruary 2003, p. 1876. It is remarkable how similar this Bundestag speech is to Willy Brandt's before the Second Gulf War. The terminology employed for arguing against war is largely borrowed from Brandt. 
multilateral decision taken within the framework of the U nited $\mathrm{N}$ ations. ${ }^{86}$ The Spiegel accused the $U$ nited States of imperialism in several articles, and stressed the role of historical lessons: 'In Paris, M oscow and Berlin, very different experiences with imperial ambitions were made, different conclusions were drawn from history.' 87 Public opinion agreed with the criticism of the U nited States. A ccording to an I psos survey, 57 per cent of Germans felt that the U nited States played a negative role in safeguarding world peace. Only 23 per cent thought that the U nited States played a positive role. 88

$M$ any intellectuals accused the $U$ nited States of no longer resisting the lure of imperialism. E rnst-Otto Czempiel, one of the leading peace researchers in G ermany, argued that the $U$ nited States have embarked on an imperial style of rule. ${ }^{89}$ Christian Tomuschat, a leading expert on international law, concurred.90 Werner Link, Ottfried N assauer, Claus L eggewie L utz Schrader argued in a similar vein, often juxtaposing historical experiences that differ between E urope and the U nited States. ${ }^{91}$ $M$ any commentators sought to distance E urope from the $U$ nited States and the Bush A dministration. Jürgen $\mathrm{H}$ abermas and J acques D errida, for example, argued that European visions for a world order are, partly due to historical experiences, different from the ones predominant in the U nited States. ${ }^{92}$

It is this juxtaposition that crossed, when done by less sophisticated thinkers than D errida and $\mathrm{H}$ abermas, the border of the reasonable and acceptable. In the eyes of some critics, the Bush Administration became the imperial evil that Germans and E uropeans had striven to overcome since W orld War II. L udwig Stiegler, the leader of the Social D emocratic caucus in the Bundestag, compared George W. Bush to the Roman Emperor A ugustus, who once sought to incorporate Germania into the R oman Empire. He also likened Dan Coats, the US ambassador in Germany, to Pjotr A brassimow, the former Soviet ambassador in East Berlin, whose powers came closer to those of a governor than an ambassador. ${ }^{93}$ Other comparisons also alluded to the allegation of U S imperialism. Walter K olbow, deputy foreign minister, alleged that Bush is 'not a partner but a dictator'. He later sought to downplay this accusation, but, for obvious reasons, his characterisation of Bush as 'a dictator of one-sided decisions' 94 hardly accomplished that. H ertha D äubler-G melin, the justice

${ }^{86}$ Gernot Erler, Verhandlungen des Deutschen Bundestags: Plenarprotokoll 15/25, 13 F ebruary 2003, p. 1890, Peter Struck, Verhandlungen des Deutschen Bundestags: Plenarprotokoll 15/25, 13 F ebruary 2003, p. 1899.

87 Erich Follath and Gerhard Spörl, 'D er entfesselte Gulliver', Spiegel, no. 12, 17 M arch 2003, p. 123.

88 Eurobarometer 60.1, N ational R eport (G ermany), A utumn 2003, pp. 17-18.

89 Ernst-Otto Czempiel, 'D ie stolpernde W eltmacht', Aus Politik und Zeitgeschichte, B 46 (2003), pp. 7-15.

90 Christian Tomuschat, 'D er selbstverliebte Hegemon: D ie U SA und der Traum von der unipolaren W elt', Internationale Politik, 58:5 (2003), pp. 39-47.

91 Werner Link, 'Imperialer oder pluralistischer F rieden? Plädoyer für eine Politik der kooperativen Balance', Internationale Politik, 58:5 (2003), pp. 48-56; Ottfried N assauer, 'A ktive A symmetrie: N eubestimmung der Sicherheitspolitik im euro-atlantischen K ontext', Blätter für deutsche und internationale Beziehungen, 48:8 (2003), pp. 946-54; Claus L eggewie, 'G lobalisierung versus Hegemonie: Zur Zukunft der transatlantischen Beziehungen', Internationale Politik und Gesellschaft, 1 (2003), pp. 87-111; L utz Schrader, 'Europas A ntwort auf Bushs Grand Strategy', WeltTrends, 42 (2004), pp. 37-50.

92 U Irike Guérot and A ndrea W itt, 'Europeas neue Geostrategie', Aus Politik und Zeitgeschichte, B 17 (2004), pp. 6-12; J acques D errida and J ürgen $\mathrm{H}$ abermas, ' $\mathrm{N}$ ach dem $\mathrm{K}$ rieg: $\mathrm{D}$ ie W iedergeburt Europas', Frankfurter Allgemeine Zeitung, 31 M ay 2003.

93 K aren A ndresen et al., 'F reund oder F eind?' Spiegel, no. 40, 30 September 2002, p. 114.

94 Walter K olbow, quoted in NTV, at: 〈http://www.ntv.de/3105930.html〉. 
minister, had no qualms comparing Bush directly to $\mathrm{Hitler}$ - not a particularly apt comparison that understandably caused much anger in the $U$ nited States. 95

In short, the habitus predisposed Germany to take an anti-war stance. I ts four dimensions rendered an unambiguous pro-war stance inconceivable. The habitus did not make an ambiguous position for war as a last resort impossible but its nature of war and world order dimensions severely undermined this reasoning. The majority, emphasising these two dimensions and interpreting the link between the war as last resort and alliance dimensions different from the ambiguous proponents of force, chastised - often in very provocative terms - the war as unjustified.

\section{Conclusion}

F or the last half-century, the $G$ erman-A merican friendship has been a cornerstone of (W est-) G erman foreign policy. G ermany's sharp disagreement with the U nited States over I raq was a major exception to this pattern. N ot only did Germany refuse to follow W ashington's lead but it also distanced itself, in quite unequivocal and angry manner, from its long-time friend. Why did the U S advocacy for war against I raq have this effect?

In order to provide a plausible explanation, we introduced - borrowing from the work of Elias - the concept of the habitus of restraint to the study of the internal dynamics of security communities. We argued that G ermany's habitus of restraint, largely distilled from the Second World War, generated a range of conceivable practices that were incompatible with Germany's perception of Washington's case for war. Washington's practices were outside the pool of tenable practices that Germany's habitus marked out. Given this mismatch, not only was there no path available to reach agreement on a course of action. The mismatch even disrupted the shared identification that had been the pillar of German-US relations for half a century.

These findings allude to the usefulness of the concept of the habitus for the study of international relations in general and research on the internal dynamics of security communities in particular. There is a three fold added value. First, the relationship between an actor's range of practices that its habitus delineates on the one hand and its perception of the practices of others on the other hand, helps in understanding patterns of conflict and co-operation. Compatibility makes co-operation possible. It provides the common ground for argumentation and bargaining, and sometimes even for what Bourdieu called 'a conductorless orchestration'. ${ }^{96}$ Incompatibility, by contrast, makes co-operation impossible and even hampers - especially if the incompatibility persists - future co-operation because it disrupts the actors' collective identity. The trans-A tlantic security community, for example, would be put to a hard test if the resort to war were constantly on its agenda and if the case made for war by some members were to persistently violate the deeply ingrained dispositions of restraint of other members.

95 Peter Gruber and J ürgen Schönstein, 'A uftrag geplatzt', Focus, no. 40, 30 September 2002, pp. 212-14.

96 Bourdieu, Practical Reason, p. 59. 
Second, the habitus draws attention to the salience of historical lessons in political decision-making. To some extent, the findings of this study echo research on historical analogies. This study concurs that authoritatively interpreted historical facts serve as orientation for actors who try to cope with a novel situation whose unfamiliarity challenges them. ${ }^{97}$ A the same time, however, this study goes beyond the notion that actors choose historical facts more or less freely and consciously in order to make up their minds about a situation. The distilled history that makes up the habitus is a second nature. M aking use of the distilled history is not a choice but a necessary element of the process through which actors cope with the world. To some extent, the findings of this study also mirror Constructivist research on foreign policy. Research on German foreign policy, for example, often points to the inadvertent salience of the lessons of Germany's militaristic past. ${ }^{98}$ This study is indebted to this research in various ways but it paints a more complex picture. It does not employ a mechanistic logic of appropriateness, according to which norms virtually determine the decisions of policymakers. Instead, this article emphasises that deeply ingrained historical interpretations merely mark out the range of conceivable practices.

Third, the habitus of restraint - the particular habitus on which this study has focused - plays a critical role for the resort to and the conduct of war. Elias's conceptualisation of a two-layered habitus, constituted by deeply ingrained constraints on the use of force and its underlying anxieties and feelings of shame, adds to existing studies on the institution of war. ${ }^{99}$ It opens up a more profound layer, firmly situated in the actors' deep background, of this institution for research. It is worth noting in this context that the habitus of restraint is not a peculiarly German phenomenon. Of course, the German habitus of restraint has its ideosyncracies for obvious historical reasons. The habitus of other nations may be constituted by different sets of constraints and different underlying anxieties and shame. $Y$ et they have a habitus of restraint nonetheless. The shame of the $M$ y $L$ ai $M$ assacre and the fear of a repetition of what happened to U S soldiers in Somalia, for example, buttress a number of habitualised constraints for the conduct of war. These constraints, in turn, help explain the U nited States' reluctance to engage in ground warfare and attempts-however tragically unsuccessful they often are-to minimise civilian casualties.

As encouraging as the findings of this study are, many more theoretical and empirical explorations are needed to gain further insights into the salience of the habitus in world politics. T wo avenues of research seem particularly important. F irst, how do actors come to select a habitus? A ctors are socialised into the habitus and, through their practices, reproduce it. Y et how exactly does this socialisation work?

97 Y uen F oong K hong, A nalogies at war: Korea, Munich, Dien Bien Phu, and the Vietnam decisions of 1965 (Princeton, N J : Princeton U niversity Press, 1992); Scott M acdonald, Rolling the Iron Dice:

Historical Analogies and Decisions to Use Military Force in Regional Contingencies (W estport: Greenwood, 2000); J effrey Record, Making War, Thinking History: Munich, Vietnam, and Presidential Uses of Force from Korea to Kosovo (A nnapolis: N aval Institute Press, 2002).

98 Thomas Berger, 'N orms, I dentity, and N ational Security in Germany and Japan', in Peter J . K atzenstein (ed.), The Culture of National Security: Norms and Identity in World Politics (N ew Y ork: Columbia U niversity Press, 1996), pp. 317-56. Thomas Banchoff, 'G erman Identity and European Integration', European Journal of International Relations, 5:3 (1999), pp. 259-89.

99 Hedley Bull, The Anarchical Society: A Study of Order in World Politics (N ew Y ork: Columbia U niversity Press, 1995), pp. 178-93; K alevi Holsti, Taming the Sovereigns: Institutional Change in International Relations (Cambridge: Cambridge U niversity Press, 2004), pp. 275-99. 
What explains why certain historical experiences become sedimented into the habitus - at times even revolutionise it - and others do not?

Second, how does the habitus interact with other ideational and material forces? The habitus enables actors to cope with the world without determining the outcome of their practices. It delineates the social parameters within which actors carry out their practices. $Y$ et within these parameters, the habitus makes a variety of practices possible. 0 ther forces explain in more detail which practices out of a range of possible practices an actor generates. 